\title{
Switching the reaction pathways of electrochemically generated $\beta$-haloalkoxysulfonium ions - synthesis of halohydrins and epoxides
}

\author{
Akihiro Shimizu, Ryutaro Hayashi, Yosuke Ashikari, Toshiki Nokami§ \\ and Jun-ichi Yoshida*
}

\author{
Full Research Paper \\ Address: \\ Department of Synthetic Chemistry and Biological Chemistry, \\ Graduate School of Engineering, Kyoto University, \\ Kyotodaigaku-Katsura, Nishikyo-ku, Kyoto 615-8510, Japan \\ Email: \\ Jun-ichi Yoshida* - yoshida@sbchem.kyoto-u.ac.jp \\ * Corresponding author \\ $\S$ Present address: Department of Chemistry and Biotechnology, \\ Graduate School of Engineering, Tottori University, 4-101 Koyama- \\ chominami, Tottori 680-8552, Japan \\ Keywords: \\ DMSO; electrosynthesis; epoxides; halohydrins; halogen cations \\ Beilstein J. Org. Chem. 2015, 11, 242-248. \\ doi:10.3762/bjoc.11.27 \\ Received: 30 November 2014 \\ Accepted: 30 January 2015 \\ Published: 13 February 2015 \\ This article is part of the Thematic Series "Electrosynthesis". \\ Guest Editor: S. R. Waldvogel \\ (c) 2015 Shimizu et al; licensee Beilstein-Institut. \\ License and terms: see end of document.
}

\begin{abstract}
$\beta$-Haloalkoxysulfonium ions generated by the reaction of electrogenerated $\mathrm{Br}^{+}$and $\mathrm{I}^{+}$ions stabilized by dimethyl sulfoxide (DMSO) reacted with sodium hydroxide and sodium methoxide to give the corresponding halohydrins and epoxides, respectively, whereas the treatment with triethylamine gave $\alpha$-halocarbonyl compounds.
\end{abstract}

\section{Introduction}

Alkene difunctionalization through three-membered ring halonium ion intermediates [1] is an important transformation in organic synthesis. Usually the halonium ions such as bromonium or iodonium ions are generated by the reaction of alkenes with $\mathrm{Br}_{2}$ and $\mathrm{I}_{2}$ [2]. However, the most straightforward method is the reaction of alkenes with halogen cations such as $\mathrm{Br}^{+}$and $\mathrm{I}^{+}$. The $\mathrm{I}^{+}$cation pool exists as reported by Filimonov et al. [3], although the used solvent is concentrated sulfuric acid which is therefore not compatible with most organic compounds.

Electrochemical oxidation [4-11] is a potent technique to generate and accumulate highly reactive cationic species in solution (the "cation pool" method) [12-17]. Although halogen cations are too unstable to accumulate in solution as "cation pools", halogen cations stabilized by an appropriate stabilizing agent that coordinates the cations can be accumulated in the solution. For example, "I" cations stabilized by acetonitrile $\left(\mathrm{CH}_{3} \mathrm{CN}\right)$ [18-20] or by trimethyl orthoformate (TMOF) [21] were reported in the literature. Recently, we reported that dimethyl sulfoxide (DMSO) can also be used to effectively stabilize halogen cations (Scheme 1) [22].

The pools of stabilized halogen cations enable alkene difunctionalization. We previously reported that the reaction of 


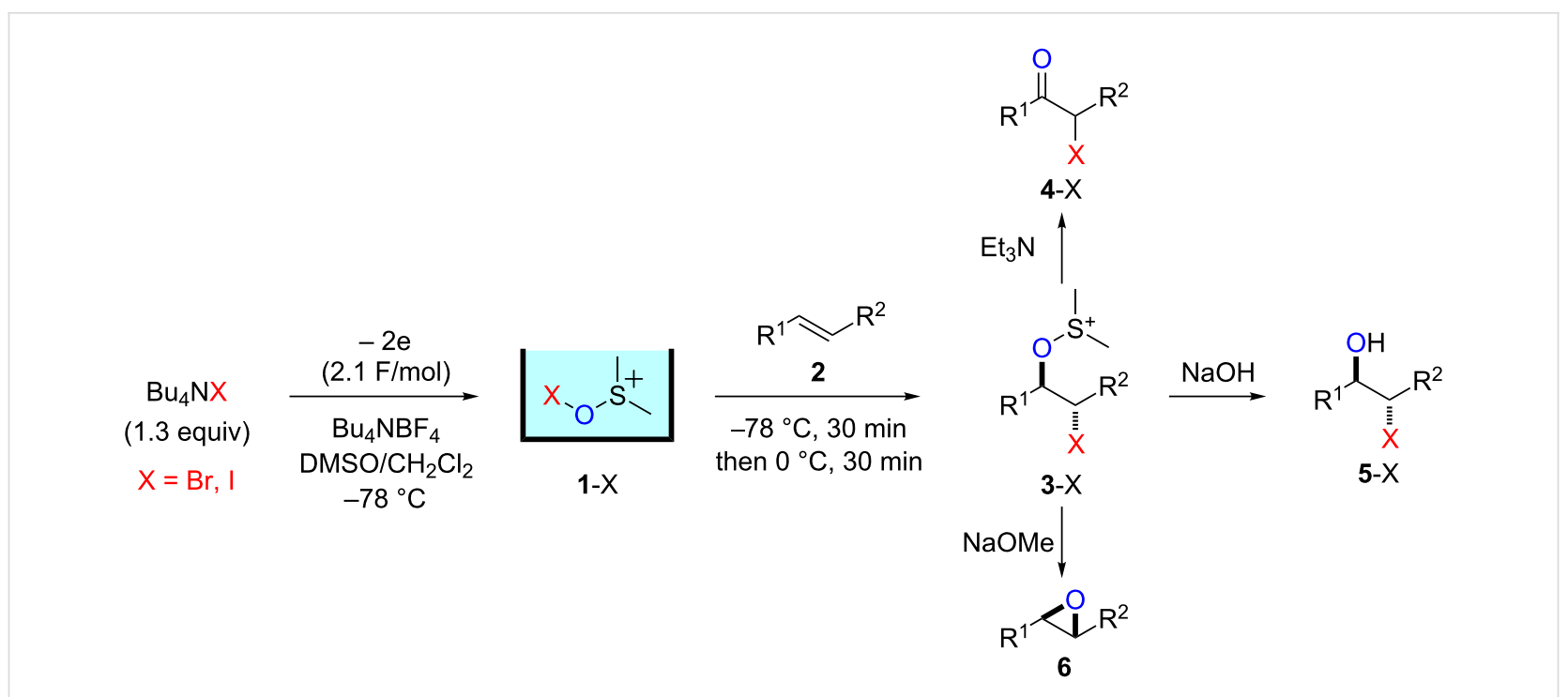

Scheme 1: Synthesis of halohydrins and epoxides through $\beta$-haloalkoxysulfonium ions generated by the reaction of alkenes with DMSO-stabilized halogen cations.

alkenes with DMSO-stabilized halogen cations such as $\mathrm{Br}^{+}$and $\mathrm{I}^{+}$gave $\beta$-haloalkoxysulfonium ions and their subsequent treatment with triethylamine gave $\alpha$-halocarbonyl compounds through Swern-Moffatt-type oxidation [23-27]. Recently reaction integration [28-31] has received significant research interest because it enhances the power and speed of organic syntheses and this is an example of integration of an electrochemical reaction and a chemical reaction using a reactive intermediate. Herein, we report that the reaction pathways of $\beta$-haloalkoxysulfonium ions can be switched to give different products by changing the base, thus expanding the utility of the present method. The treatment of $\beta$-haloalkoxysulfonium ions 3-X with sodium hydroxide gave the corresponding halohydrins 5-X, while the treatment with sodium methoxide gave epoxides 6 (Scheme 1).

\section{Results and Discussion Reactions of $\beta$-bromoalkoxysulfonium ions generated from (Z)-5-decene}

We first examined the reactions of $\beta$-bromoalkoxysulfonium ion 3a-Br generated by the reaction of $(Z)$-5-decene (2a) with $\mathrm{Br}^{+} / \mathrm{DMSO}$ (1-Br) [21] (Scheme 1, $\mathrm{X}=\mathrm{Br}$ ). $\mathrm{Bu}_{4} \mathrm{NBr}$ in DMSO/ $\mathrm{CH}_{2} \mathrm{Cl}_{2}(1: 9 \mathrm{v} / \mathrm{v})$ was electrochemically oxidized at $-78^{\circ} \mathrm{C}$ in a divided cell using $\mathrm{Bu}_{4} \mathrm{NBF}_{4}$ as a supporting electrolyte until $2.1 \mathrm{~F} / \mathrm{mol}$ of electricity was applied. After addition of $\mathbf{2 a}$ to the solution, the mixture was stirred at $0{ }^{\circ} \mathrm{C}$ to give $\mathbf{3 a}-\mathrm{Br}$, which was characterized by NMR spectroscopy [22]. The treatment of 3a- $\mathrm{Br}$ with triethylamine gave $\alpha$-bromoketone $\mathbf{4 a - B r}$ in $83 \%$ yield [22]. However, the treatment of $\mathbf{3 a - B r}$ with $\mathrm{NaOH}$ gave bromohydrin $\mathbf{5 a - B r}$ in $89 \%$ yield as shown in Table 1 . These phenomena can be explained as follows: Due to the steric repul- sion, triethylamine cannot attack the sulfur atom in $\mathbf{3 a - B r}$ and acts as base to abstract a proton attached to the carbon adjacent to the sulfur. The formed carbanion part of the resulting sulfur ylide abstracts a proton attached to the carbon adjacent to the oxygen to give $\alpha$-bromoketone $\mathbf{4 a - B r}$ by the Swern-Moffatttype oxidation mechanism [23-27]. On the other hand, the hydroxide ion attacks the sulfur atom in $\mathbf{3 a - B r}$ and cleaves the $\mathrm{S}-\mathrm{O}$ bond to give the alkoxide ion, which is protonated by water to give bromohydrin $\mathbf{5 a}-\mathrm{Br}$ (Scheme 2). The stereochemistry determined by NMR (5a-Br was synthesized using NBS according to the literature; see Supporting Information File 1) indicated that the addition of $\mathrm{Br}^{+}$and DMSO across the $\mathrm{C}-\mathrm{C}$ double bond was anti-selective, which is consistent with the results reported previously [22].

Treatment of 3a-Br with $\mathrm{NaOMe}$ resulted in a different product, namely epoxide 6a in $95 \%$ yield. In this case, the methoxide ion attacks the sulfur atom and cleaves the $\mathrm{S}-\mathrm{O}$ bond under formation of an alkoxide ion. The latter intramolecularly attacks the carbon atom bearing the bromine substituent to give epoxide $\mathbf{6 a}$ (Scheme 2). Presumably, the protonation of the alkoxide ion with $\mathrm{MeOH}$ is slower than the intramolecular nucleophilic attack. We could not exclude the possibility that a protonated DMSO molecule presumably generated by the reaction of $\mathbf{3 a}-\mathrm{Br}$ with the hydroxide ion protonates the alkoxide ion to give 5a-Br, while a methylated DMSO molecule presumably generated by the reaction of $\mathbf{3 a}-\mathrm{Br}$ with the methoxide ion cannot protonate the alkoxide ion, which converts to 6a. The stereochemistry determined by NMR [32] is consistent with a mechanism involving the back-side attack of the alkoxide ion to form epoxide 6a. 
Table 1: Reaction of $3 a-X(X=B r, I)$ with different bases. ${ }^{a}$

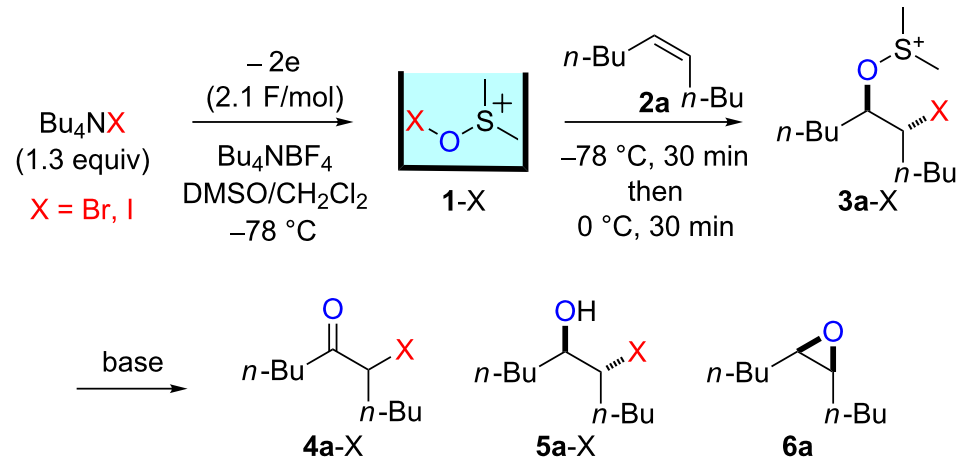

$\%$ Yield of product ${ }^{b}$

$\mathrm{X}=\mathrm{Br} \quad \mathrm{X}=\mathrm{I}$

\begin{tabular}{|c|c|c|c|c|c|c|}
\hline \multirow[b]{2}{*}{ Base } & & \\
\hline & $4 a-B r$ & $5 a-B r$ & $6 a$ & $4 a-I r$ & $5 a-1$ & $6 a$ \\
\hline $\mathrm{Et}_{3} \mathrm{~N} / \mathrm{CH}_{2} \mathrm{Cl}_{2}$ & 83 & ND & ND & 85 & ND & 1 \\
\hline $\mathrm{NaOH} / \mathrm{H}_{2} \mathrm{O}$ & ND & 89 & 2 & ND & 84 & 1 \\
\hline $\mathrm{NaOMe} / \mathrm{MeOH}$ & ND & ND & 95 & ND & ND & 96 \\
\hline
\end{tabular}

${ }^{a}$ The electrolysis was carried out using 1.3 equiv of $\mathrm{Bu}_{4} \mathrm{NBr}$ or $\mathrm{Bu}_{4} \mathrm{NI}$ (based on the alkene which was added after electrolysis) with $2.1 \mathrm{~F} / \mathrm{mol}$ of electricity based on $\mathrm{Bu}_{4} \mathrm{NBr}$ or $\mathrm{Bu}_{4} \mathrm{NI}$. ' ${ }^{\text {b }}$ ields were determined by $\mathrm{GC}$.

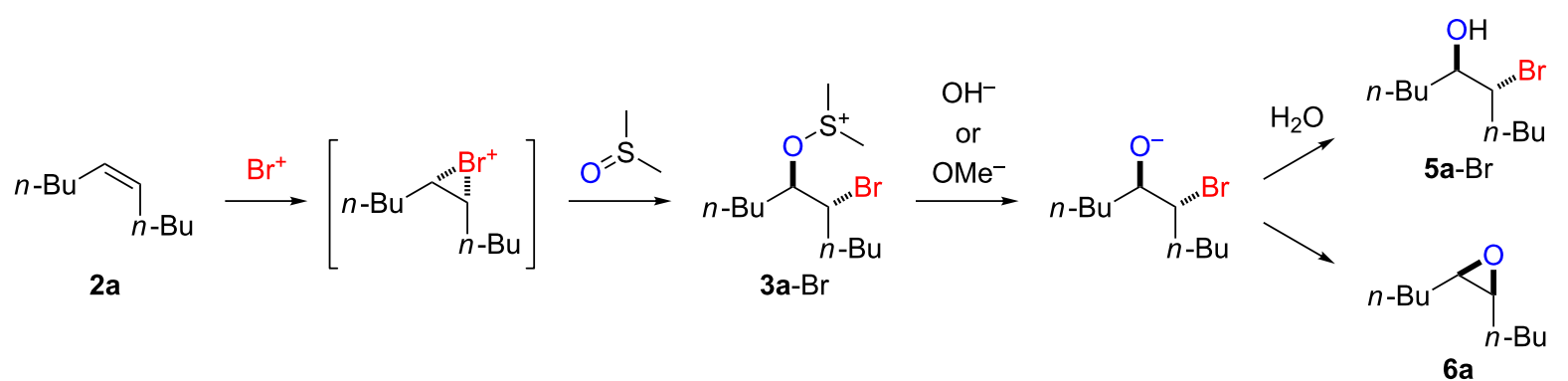

Scheme 2: Proposed reaction mechanisms for the syntheses of bromohydrin $\mathbf{5 a - B r}$ and epoxide $\mathbf{6 a}$.

\section{Reactions of $\beta$-iodoalkoxysulfonium ions generated from $(Z)-5$-decene}

We next examined the reactions of $\beta$-iodoalkoxysulfonium ion 3a-I generated by the reaction of $(Z)$-5-decene (2a) with $\mathrm{I}^{+} / \mathrm{DMSO}(1-\mathrm{I})$ cation pool [22] (Scheme $1, \mathrm{X}=\mathrm{I}$ ). $\mathrm{Bu}_{4} \mathrm{NI}$ in $\mathrm{DMSO} / \mathrm{CH}_{2} \mathrm{Cl}_{2}(1: 9 \mathrm{v} / \mathrm{v})$ was electrochemically oxidized at -78 ${ }^{\circ} \mathrm{C}$ in a divided cell using $\mathrm{Bu}_{4} \mathrm{NBF}_{4}$ as a supporting electrolyte until $2.1 \mathrm{~F} / \mathrm{mol}$ of electricity was applied. After addition of $\mathbf{2 a}$ to the solution, the mixture was stirred at $0{ }^{\circ} \mathrm{C}$ to give $\mathbf{3 a}-\mathrm{I}$, which was characterized by NMR spectroscopy [22]. The treatment of 3a-I with triethylamine gave $\alpha$-iodoketone $4 \mathbf{a}-\mathrm{I}$ in $85 \%$ yield as we reported previously [22]. However, the treatment of 3a-I with $\mathrm{NaOH}$ and $\mathrm{NaOMe}$ gave iodohydrin 5a-I in $84 \%$ yield and epoxide $6 \mathbf{a}$ in $96 \%$ yield, respectively (Table 1). The stereochemistry as determined by NMR (5a-I was synthesized using
$\mathrm{I}_{2}$ and $\mathrm{H}_{2} \mathrm{O}_{2}$; see Supporting Information File 1) indicated that the addition of $\mathrm{I}^{+}$and DMSO across the $\mathrm{C}-\mathrm{C}$ double bond was anti-selective as anticipated.

\section{Synthesis of halohydrins and epoxides from various alkenes}

The present method was successfully applied to the synthesis of halohydrins and epoxides from various alkenes. The reactions of alkenes with 1-X followed by the treatment with $\mathrm{NaOH}$ gave the corresponding halohydrins as shown in Table 2 . The reactions of $E$ and $Z$ isomers of 1-phenyl-1-propene (2d) with 1-Br gave $\mathbf{5 d}-\mathrm{Br}$ and $\mathbf{5 d}$ '- $\mathrm{Br}$, respectively (Table 2, entries 7 and 9), indicating the anti-addition of $\mathrm{Br}^{+}$and DMSO across the $\mathrm{C}-\mathrm{C}$ double bond. The reaction with 1-I also gave the anti-addition products (Table 2, entries 8 and 10). Therefore, the reaction is 
Table 2: Synthesis of halohydrins by the reaction of $1-\mathrm{X}$ with alkenes followed by the treatment with $\mathrm{NaOH}{ }^{a}$

\begin{tabular}{|c|c|c|c|c|c|c|}
\hline & $\begin{array}{c}\mathrm{Bu}_{4} \mathrm{NX} \\
\text { (1.3 equiv) }\end{array}$ & $\begin{array}{c}-2 \mathrm{e} \\
\underset{(2.1 \mathrm{~F} / \mathrm{mol})}{\longrightarrow} \\
\underset{\mathrm{Bu}_{4} \mathrm{NBF}_{4}}{\longrightarrow} \\
\mathrm{DMSO} / \mathrm{CH}_{2} \mathrm{Cl}_{2} \\
-78{ }^{\circ} \mathrm{C}\end{array}$ & $\frac{1-x}{e_{-2}}$ & 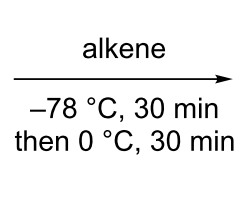 & $\frac{\text { aq } \mathrm{NaOH}}{25^{\circ} \mathrm{C}, 1 \mathrm{~h}}$ & halohydrin \\
\hline Entry & & Alkene & & Product & & Yield $(\%)^{b}$ \\
\hline $\begin{array}{l}1 \\
2\end{array}$ & & $\bigcap_{2 a}^{n-B u}$ & & $\overbrace{5 \mathrm{a}-\mathrm{Br}, 5 \mathrm{n}-\mathrm{-}}^{\mathrm{OH}}$ & & $\begin{array}{l}\text { 5a-Br: } 87 \\
\text { 5a-I: } 84^{\mathrm{C}}\end{array}$ \\
\hline 3 & & & & & & $\begin{array}{l}\text { 5b-Br: } 74 \\
\text { (trans:cis = 79:21) }\end{array}$ \\
\hline 4 & & $\begin{array}{l}\mathbf{2 b} \\
=72: 28)\end{array}$ & & $5 \mathbf{b}-\mathrm{Br}, \mathbf{5 b - \mathrm { I }}$ & & $\begin{array}{l}\text { 5b-l: } 94 \\
\text { (trans:cis = 71:29) }\end{array}$ \\
\hline $\begin{array}{l}5 \\
6\end{array}$ & & $\begin{array}{c}\mathrm{C}_{10} \mathrm{H}_{21} \\
2 \mathrm{c}\end{array}$ & & $\underset{5 \mathrm{c}-\mathrm{Br}, 5 \mathrm{c}-\mathrm{I}}{n-\mathrm{C}_{10} \mathrm{H}_{21}}$ & & $\begin{array}{l}\text { 5c-Br: } 57 \\
\text { 5c-I: } 53\end{array}$ \\
\hline $\begin{array}{l}7 \\
8\end{array}$ & & $(E)-2 d$ & & 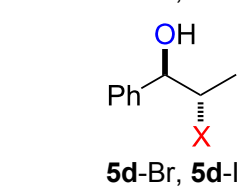 & & $\begin{array}{l}\text { 5d-Br: } 73 \\
\text { 5d-I: } 35\end{array}$ \\
\hline $\begin{array}{l}9 \\
10\end{array}$ & & $\underset{(Z)-2 d}{P h}$ & & 5d'-Br, 5d'-1 & & $\begin{array}{l}\text { 5d'-Br: } 75 \\
\text { 5d'-I: } 51\end{array}$ \\
\hline
\end{tabular}

aThe electrolysis of $\mathrm{Bu}_{4} \mathrm{NBr}$ and $\mathrm{Bu}_{4} \mathrm{NI}$ was carried out using 1.3 equiv of $\mathrm{Bu}_{4} \mathrm{NX}$ (based on the alkene which was added after the electrolysis) with 2.1 $\mathrm{F} / \mathrm{mol}$ of electricity based on $\mathrm{Bu}_{4} \mathrm{NX}$. ${ }^{\mathrm{b}}$ Isolated yield. ${ }^{C}$ Yield was determined by $\mathrm{GC}$.

stereospecific, and the stereochemistry is consistent with the proposed reaction mechanism (Scheme 2). The addition of $\mathrm{Br}^{+}$ or $\mathrm{I}^{+}$and DMSO to unsymmetrically substituted olefins $\mathbf{2 c}$ and 2d regioselectively gave bromohydrins as single regioisomers (Table 2, entries 5-10). The regioselectivity of the products can be explained by the stability of carbocations (benzyl $>$ secondary $>$ primary). In the case of terminal alkene $\mathbf{2 c}, \mathrm{Br}$ and I were introduced to a primary carbon atom, whereas $\mathrm{OH}$ was introduced to a secondary carbon atom. In the case of styrene derivative $\mathbf{2 d}, \mathrm{Br}$ and I were introduced to a secondary carbon, whereas $\mathrm{OH}$ was introduced to the benzyl carbon. DMSO seems to attack the more positively charged carbon of the threemembered ring bromonium ion or iodonium ion.

The reaction of 1-X with alkenes followed by the treatment with $\mathrm{NaOMe}$ gave the corresponding epoxides as shown in Table 3.
Alkenes having an alkoxycarbonyl group gave the corresponding epoxides in moderate yields (Table 3, entries 11-14). Diene $\mathbf{2 f}$ reacted with $\mathbf{1 - B r}$ and $\mathbf{1 - I}$ to give monoepoxide $\mathbf{6 f}$ in moderate yields (Table 3, entries 13 and 14). Interestingly, $\mathbf{2 g}$ reacted with 1-Br to give $\mathbf{6 g}$ but not with $\mathbf{1 - I}$ (Table 3, entries 15 and 16), although the reason is not clear at present. The facial selectivity of the reaction is the opposite to that of the epoxidation using conventional reagents such as $m$-chloroperoxybenzoic acid (mCPBA) which epoxidizes alkenes from the less hindered face $[33,34]$. In this reaction, $\mathrm{Br}^{+}$adds to the $\mathrm{C}-\mathrm{C}$ double bond of $\mathbf{2 g}$ from the less hindered face to form the corresponding three-membered ring bromonium ion intermediate. Subsequently, DMSO attacks the bromonium ion from the more hindered face to form the corresponding $\beta$-haloalkoxysulfonium ion. The treatment of the $\beta$-haloalkoxysulfonium ion with $\mathrm{NaOMe}$ cleaves the $\mathrm{O}-\mathrm{S}$ bond to generate the alkoxide 
Table 3: Synthesis of epoxides by the reaction of $1-\mathrm{X}$ with alkenes followed by the treatment with $\mathrm{NaOMe}{ }^{\mathrm{a}}$

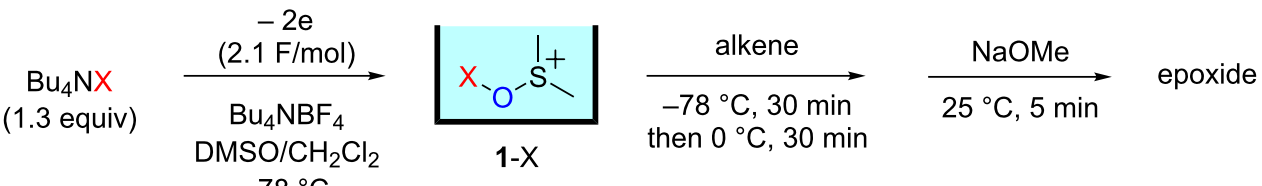

$$
\begin{aligned}
& -78^{\circ} \mathrm{C}
\end{aligned}
$$

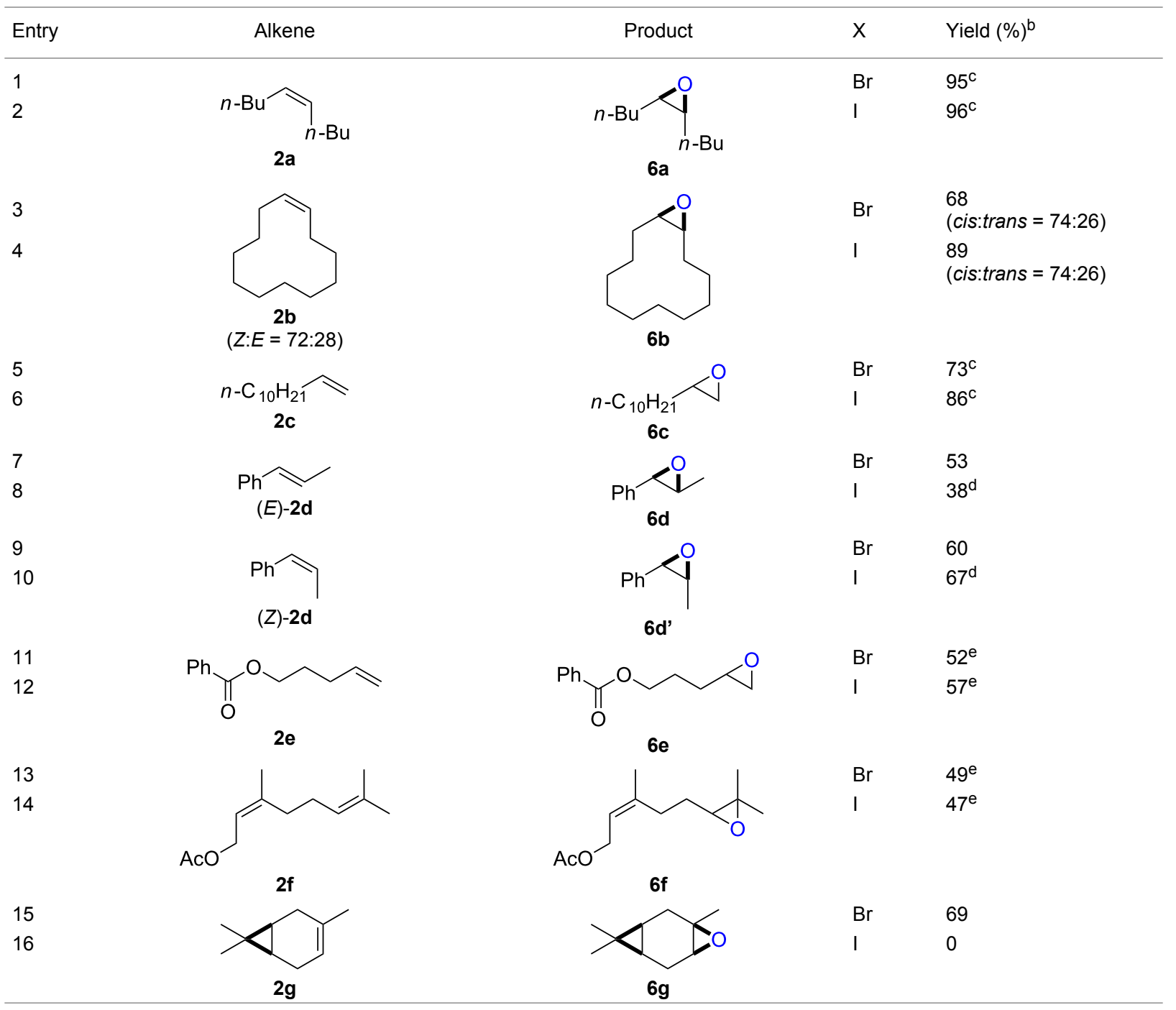

aThe electrolysis was carried out using 1.3 equiv of $\mathrm{Bu}_{4} \mathrm{NBr}$ or $\mathrm{Bu}_{4} \mathrm{NI}$ (based on the alkene which was added after electrolysis) with $2.1 \mathrm{~F} / \mathrm{mol}$ of electricity based on $\mathrm{Bu}_{4} \mathrm{NBr}$ or $\mathrm{Bu}_{4} \mathrm{NI}$. ' Isolated yield. ${ }^{C}$ Yield was determined by $\mathrm{GC}$. ${ }^{\mathrm{d}} 2.0$ Equiv of $\mathrm{Bu}_{4} \mathrm{NI}$ was used. ${ }^{e} \mathrm{Reacted}$ with 2.5 equiv of $\mathrm{NaOMe}$ for $2 \mathrm{~h}$.

ion, which attacks the carbon atom bearing bromine to give epoxide $\mathbf{6 g}$. Therefore, the installation of the oxygen atom takes place from the more hindered face.

\section{Reaction mechanism}

To confirm the mechanism shown in Scheme 2, the experiment was repeated using ${ }^{18} \mathrm{O}$-labeled DMSO $\left(96 \%{ }^{18} \mathrm{O}\right) / \mathrm{CH}_{2} \mathrm{Cl}_{2}$ $(1: 50 \mathrm{v} / \mathrm{v})$. As outlined in Scheme 3, epoxide $6 \mathbf{c}$ containing ${ }^{18} \mathrm{O}$ $\left(94 \%{ }^{18} \mathrm{O}\right)$ was obtained in $81 \%$ yield, indicating that the oxygen atom in the product originated from DMSO. Since ${ }^{18} \mathrm{O}-$ labeled DMSO can be easily obtained from $\mathrm{H}_{2}{ }^{18} \mathrm{O}$ [35], the present transformation serves as a convenient method for synthesizing ${ }^{18} \mathrm{O}$-labeled epoxides, that can be used for various mechanistic and biological studies.

\section{Conclusion}

In conclusion, we found that the reaction pathways of $\beta$-haloalkoxysulfonium ions generated by the reaction of elec- 


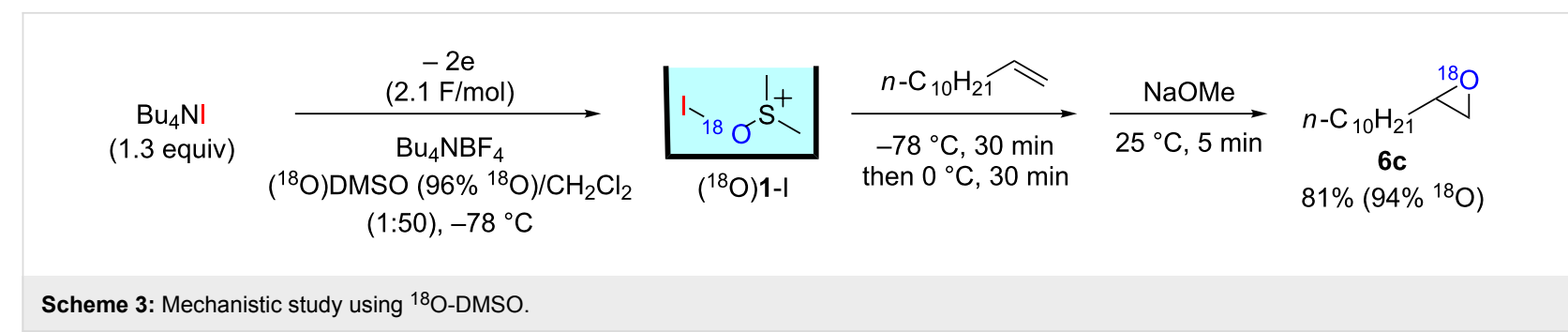

trogenerated $\mathrm{Br}^{+}$and $\mathrm{I}^{+}$stabilized by dimethyl sulfoxide (DMSO) can be switched by changing the nature of the base. The present transformation serves as stereospecific route to halohydrins and epoxides from alkenes. The method is also useful for synthesizing ${ }^{18} \mathrm{O}$-labeled epoxides.

\section{Supporting Information}

\section{Supporting Information File 1}

Experimental and analytical data.

[http://www.beilstein-journals.org/bjoc/content/

supplementary/1860-5397-11-27-S1.pdf]

\section{Acknowledgements}

We thank the Ministry of Education, Culture, Sports, Science \& Technology, Japan, for a Grant-in-Aid for Scientific Research on Innovative Areas, 2105. We also thank Taiyo Nippon Sanso Corporation for partial support of this work including providing $\mathrm{H}_{2}{ }^{18} \mathrm{O}$.

\section{References}

1. Olah, G. A.; Laali, K. K.; Wang, Q.; Prakash, G. K. S. Onium ions; Wiley: New York, 1998; pp 246-268.

2. Rodriguez, J.; Dulcère, J.-P. Synthesis 1993, 1177-1205. doi:10.1055/s-1993-26022

3. Chaikovski, V. K.; Kharlova, T. S.; Filimonov, V. D.; Saryucheva, T. A. Synthesis 1999, 748-750. doi:10.1055/s-1999-3475

4. Moeller, K. D. Tetrahedron 2000, 56, 9527-9554. doi:10.1016/S0040-4020(00)00840-1

5. Sperry, J. B.; Wright, D. L. Chem. Soc. Rev. 2006, 35, 605-621. doi:10.1039/b512308a

6. Yoshida, J.; Kataoka, K.; Horcajada, R.; Nagaki, A. Chem. Rev. 2008, 108, 2265-2299. doi:10.1021/cr0680843

7. Kirste, A.; Elsler, B.; Schnakenburg, G.; Waldvogel, S. R. J. Am. Chem. Soc. 2012, 134, 3571-3576. doi:10.1021/ja211005g

8. Finney, E. E.; Ogawa, K. A.; Boydston, A. J. J. Am. Chem. Soc. 2012, 134, 12374-12377. doi:10.1021/ja304716r

9. Sumi, K.; Saitoh, T.; Natsui, K.; Yamamoto, T.; Atobe, M.; Einaga, Y.; Nishiyama, S. Angew. Chem., Int. Ed. 2012, 51, 5443-5446. doi:10.1002/anie.201200878

10. Morofuji, T.; Shimizu, A.; Yoshida, J. J. Am. Chem. Soc. 2013, 135, 5000-5003. doi:10.1021/ja402083e

11. Yamaguchi, Y.; Okada, Y.; Chiba, K. J. Org. Chem. 2013, 78, 2626-2638. doi:10.1021/jo3028246
12. Yoshida, J.; Suga, S.; Suzuki, S.; Kinomura, N.; Yamamoto, A.; Fujiwara, K. J. Am. Chem. Soc. 1999, 121, 9546-9549. doi:10.1021/ja9920112

13. Suga, S.; Suzuki, S.; Yamamoto, A.; Yoshida, J. J. Am. Chem. Soc. 2000, 122, 10244-10245. doi:10.1021/ja002123p

14. Yoshida, J.; Suga, S. Chem. - Eur. J. 2002, 8, 2650-2658. doi:10.1002/1521-3765(20020617)8:12<2650::AID-CHEM2650>3.0.C $0 ; 2-S$

15. Suzuki, S.; Matsumoto, K.; Kawamura, K.; Suga, S.; Yoshida, J. Org. Lett. 2004, 6, 3755-3758. doi:10.1021/ol048524h

16. Suga, S.; Matsumoto, K.; Ueoka, K.; Yoshida, J. J. Am. Chem. Soc. 2006, 128, 7710-7711. doi:10.1021/ja0625778

17. Matsumoto, K.; Sanada, T.; Shimazaki, H.; Shimada, K.; Hagiwara, S.; Fujie, S.; Ashikari, Y.; Suga, S.; Kashimura, S.; Yoshida, J. Asian J. Org. Chem. 2013, 2, 325-329. doi:10.1002/ajoc.201300017

18. Miller, L. L.; Kujawa, E. P.; Campbell, C. B. J. Am. Chem. Soc. 1970, 92, 2821-2825. doi:10.1021/ja00712a036

19. Miller, L. L.; Watkins, B. F. J. Am. Chem. Soc. 1976, 98, 1515-1519. doi:10.1021/ja00422a039

20. Midorikawa, K.; Suga, S.; Yoshida, J. Chem. Commun. 2006, 3794-3796. doi:10.1039/b607284d

21. Shono, T.; Matsumura, Y.; Katoh, S.; Ikeda, K.; Kamada, T. Tetrahedron Lett. 1989, 30, 1649-1650. doi:10.1016/S0040-4039(00)99543-1

22. Ashikari, Y.; Shimizu, A.; Nokami, T.; Yoshida, J. J. Am. Chem. Soc. 2013, 135, 16070-16073. doi:10.1021/ja4092648

23. Kornblum, N.; Powers, J. W.; Anderson, G. J.; Jones, W. J.; Larson, H. O.; Levand, O.; Weaver, W. M. J. Am. Chem. Soc. 1957, 79, 6562. doi:10.1021/ja01581a057

24. Mancuso, A. J.; Swern, D. Synthesis 1981, 165-185. doi:10.1055/s-1981-29377

25. Phan, T. B.; Nolte, C.; Kobayashi, S.; Ofial, A. R.; Mayr, H. J. Am. Chem. Soc. 2009, 131, 11392-11401. doi:10.1021/ja903207b

26. Ashikari, Y.; Nokami, T.; Yoshida, J. J. Am. Chem. Soc. 2011, 133, 11840-11843. doi:10.1021/ja202880n

27. Ashikari, Y.; Nokami, T.; Yoshida, J. Org. Biomol. Chem. 2013, 11, 3322-3331. doi:10.1039/c3ob40315g

28. Schmidt, B. Pure Appl. Chem. 2009, 78, 469-476. doi:10.1351/pac200678020469

29. Enders, D.; Hüttl, M. R. M.; Grondal, C.; Raabe, G. Nature 2006, 441, 861-863. doi:10.1038/nature04820

30. Yoshida, J.; Saito, K.; Nokami, T.; Nagaki, A. Synlett 2011, 1189-1194. doi:10.1055/s-0030-1259946

31. Suga, S.; Yamada, D.; Yoshida, J. Chem. Lett. 2010, 39, 404-406. doi:10.1246/cl.2010.404

32. Brimeyer, M. O.; Mehrota, A.; Quici, S.; Nigam, A.; Regen, S. L. J. Org. Chem. 1980, 45, 4254-4255. doi:10.1021/jo01309a047

33. Gianini, M.; von Zelewsky, A. Synthesis 1996, 702-706. doi:10.1055/s-1996-4280 
34. Majetich, G.; Shimkus, J.; Li, Y. Tetrahedron Lett. 2010, 51 , 6830-6834. doi:10.1016/j.tetlet.2010.10.068

35. Fenselau, A. M.; Moffatt, J. G. J. Am. Chem. Soc. 1966, 88, 1762-1765. doi:10.1021/ja00960a033

\section{License and Terms}

This is an Open Access article under the terms of the Creative Commons Attribution License

(http://creativecommons.org/licenses/by/2.0), which permits unrestricted use, distribution, and reproduction in any medium, provided the original work is properly cited.

The license is subject to the Beilstein Journal of Organic Chemistry terms and conditions:

(http://www.beilstein-journals.org/bjoc)

The definitive version of this article is the electronic one which can be found at: doi:10.3762/bjoc. 11.27 